\title{
An Industry in Decline: Can U.S. Horse Racing Turn the Corner?
}

\author{
David Lynn Hoffman \\ Metropolitan State University of Denver \\ Debora J. Gilliard \\ Metropolitan State University of Denver \\ Sally Baalbaki-Yassine \\ Metropolitan State University of Denver
}

\begin{abstract}
Horse tracks once were at the height of their popularity when it was one of the few options for disposable income and use of leisure time. However, horse tracks have declined in popularity, have seen decreased revenue, an aging target market, and are less attractive to younger generations who are tethered to their cell phones. Given the increasing regulation, market trends, and decreasing revenues can the industry turn the corner to a better home stretch?
\end{abstract}

Keywords: racing, declining industry, marketing in a declining industry

\section{INTRODUCTION}

Your perspective depends on where you are and the lens you see the world through.

Magic Feet comes down the muddy backstretch ahead but is challenged by Dueller for several furlongs. At the turn Magic Feet bursts ahead hitting a puddle and sending mud to the horses behind him. Dueller's googles become smattered with mud and rain, he shakes his head, and is confused about where he is. The jockey flips up his muddied googles, sees somewhat better than the horse, and tries to coach him into a gap but the split-second indecision moves him into second place. Long Rider moves up from the outside to challenge Dueller.

Five-year-old Sally at the finish line screams that her favorite horse won (she likes Magic Feet's colors). The announcer in the tower looks at the video to confirm the order of the finish and that indeed Magic Feet took first. The stewards huddle over the high powered camera video, push the resolution to distance, and determine that Dueller took second by a quarter inch over Long Rider. The stewards (judges) conference delays announcement of the second third and fourth place winners. Sally's Dad lost his exacta, but her uncle won the quinella (see appendix 1 on terms). James Jones, the Executive Director of Return the Glory Racetrack, is pleased at the interesting finish that encourages his clients to keep engaged. He is somewhat disturbed that many individuals are doing side bets on the apron outside the building but on his property. These side bets do not go through his system, so the track receives no revenue from them. If he cracks down on them they will not return for any bets through his system, use 
his restaurant, or purchase other amenities. John Stalworth, the owner of Dueller, strides out to see what happened thinking about what could he do differently to train the horse how to deal with a muddy track and impaired vision. Stella Halworth, a state commissioner, watches inside the grand stand and is hopeful that there will not be any challenges to the order of finish and that the medical testing of the winners will show no use of unlawful medication. The track Veterinarian relaxes- no animals broke down during the race especially in front of the grandstand. What is the view of most of the public who were not there? Will Sally come back when she grows up?

\section{HISTORY}

\section{Early History}

The very first horse race ran in the U.S. was when the Newmarket course was established in 1665 (History of Horse racing 2009). The industry has grown and changed substantially in the last 350 years. Organized horse racing became more established with the advent of the American Stud Book in 1868. By 1894 there were 314 tracks in the United States. Quarter horse racing started earlier in 1674 with two horses racing down a village street or lane (History of Horse Racing, 2009). This developed into racing at the shorter distance of a quarter mile or 400 meters hence the name (These horses start fast and run at a sprint for the entire quarter mile). There is less jockeying for position, turns are rare, and the horses are sometimes closely grouped at the finish requiring photo finishes. The Arabian horse was developed by the Bedouins in the Middle east for their endurance over long distances. They have more Type I fiber muscles allowing them to run for longer distances. Thoroughbreds race at several different distances from 5 to 12 furlongs (History of Horse Racing, 2009).

Although there was an anti-gambling movement in the early 1900s that negatively impacted the industry, pari-mutuel betting was introduced in 1908 which led to an increased popularity in the sport (History of Horse Racing,2009). The 1970s brought off track betting and the 1978 Interstate Horse Racing Act that regulates betting across state lines (Interstate Horse Racing, 1978). An amendment to the Act in 2000 allowed telephone and interactive wagers Interstate Horse Racing Act, 1978; 2000). There were 7,984 race days in 1995, but by 2013 there were only 5,556 race days (Innovate Racing, 2015).

Today, the U.S. Horse Racing industry is in decline. Annual growth was at $-1.20 \%$ between 2012 and 2017 and annual growth is expected to be at- $0.4 \%$ through 2022 . Industry revenue is expected to fall $0.8 \%$ in 2017 (Alvarez, 2017). Globally, the industry is doing well. What is happening to the U.S. Horse Racing Industry? Can companies survive? Will horse racing exist in the U.S. in ten years?

\section{THE INDUSTRY}

\section{Issues Facing the Industry \\ Customer Base}

The typical person betting on horses is a male over age 50. Typically, these individuals have more leisure time, disposable income, and grew up with horse racing as a past time activity (Alvarez, 2017; IBIS World, 2018). Consumers over age 56 make up 45\% of the demographic market, consumers age 3555 are $43 \%$ of the market and consumers aged 34 and younger are $12 \%$ of the market. Because of the focus on older consumers, the industry has neglected baby boomers and millennial generations (Alvarez, 2017). A January 2016 Harris Poll reported that 1\% of Americans list horse racing as a favorite sport, and it ranked as the $13^{\text {th }}$ most popular sport just behind swimming and track \& field. By comparison, in 1985, horse racing ranked the $8^{\text {th }}$ most popular sport and $4 \%$ of Americans ranked it as their favorite sport (Rhodes, 2016). It is difficult to convince casual bettors and younger consumers to bet on horses because many do not have the patience to learn the complicated betting processes (Pandell, 2016).

Younger consumers also have many other options on how to spend their leisure time and dollars. Lotteries, casinos, movies, other sports, are just a few of the leisure time activities that the horse racing industry acknowledges as major competitors for consumer leisure dollars. In recent years, a number of 
actions have been taken to attract the younger generation to horse racing. Derby Jackpot is an online gambling site that has attracted younger consumers (Pandell, 2016).

Horse racing is the only federally approved online gambling for consumers. It is also regulated by many state laws. Racinos (combined horse racing tracks and casinos) are legal in ten states and many horse racing track operators have expanded their business to include slot machines along with some other casino games such as blackjack, poker, and roulette (IBIS, 2018). Horse track operators are trying to attract younger customers to the track by offering music and food festivals, free merchandise (T-shirts and caps), family nights, drink specials, carnivals, instant racing machines, and popular music performers. Churchill Downs, Inc. operates TwinSpires.com, an online gambling site. Many tracks are now advertising on social media and developing smart phone applications. In 2013, the Jockey Club attended the SXSW musical festival in Austin, Texas, in order to market to the younger generation (Alvarez, 2017).

\section{Treatment of Horses}

Good racing horses are expensive to buy and train and have a short lifespan in the industry. Horse owners make money through the betting process. The industry earns revenue through the total amount of money bet on races - this is known as the handle. About $82 \%$ of the handle goes to the winning bettors (Alvarez, 2017; IBIS, 2018). The track operator and horsemen split the remaining $18 \%$ of the bets and of this about 3.5\% must be paid for state excise taxes. To recoup costs and keep horses running longer, the use of drugs has become an issue. Painkillers, anabolic steroids, muscle relaxants, and bronchodilators medications are commonly used. Animal rights activists are trying to change these practices. Millennials are concerned about the environment, animal treatment, and other social issues so what they perceive as abuse of horses keeps them away (Alvarez, 2017; IBIS World, 2018).

\section{Global Market for Horse Racing}

Although declining in popularity in the United States, horse racing remains a popular sport in many countries such as Japan, Hong Kong, United Kingdom, Australia, France, New Zealand, and South Korea (Alvarez, 2017; Horse racing fading in revenue, popularity, 2016; American horse racing versus the world, 2017).

In the United Kingdom, horse racing rules and regulations have been in place for over 250 years and the industry is governed by the British Horseracing Authority. The Grand National and Royal Ascot are two of most prestigious races in the world. Bets are primarily made through bookmakers who offer fixed odds and betting firms may take bets in stores and online (The Jockey Club, 2017).

Horse racing in New Zealand was established in the 1800s (American horse racing versus the world, 2017). The industry is governed by the New Zealand Thoroughbred Racing Inc. Major races include the Group 1 Auckland Cup, New Zealand Cup and the Karaka Million. All betting is controlled through the Totalisator Agency Boards (The Jockey Club, 2017).

The first horse race in Australia was held in 1810 and top races include the Golden Slipper Stakes, Sydney Cup and the Melbourne Cup (A closer look at why the horse racing industry needs innovation and a brief history of the sport, 2018). Racing is governed by the Australian Racing Board along with other organizations. Bookmakers offer fixed odds for betting at the race course and totaliser agency boards offer both on and off-course pari-mutuel betting.

The U.S. racing industry is changing as a result of global competition. Local racetracks are changing some criteria for which horses may run in a race (Mullen, 2017). Typically, a horse must run and win/place/show in certain top American races in order to be eligible to compete in a major U.S. horse race. Churchill Downs has changed its criteria and will allow horses that run well in two stakes in Japan to qualify for its Derby (Mullen, 2017). The New York Racing Association (NYRA) now reserves a spot in the Belmont Stakes for a Japan-based horse and gives a \$1 million bonus to a Japan-based horse that wins. In March of 2017, the NYRA announced a partnership with Hoppegarten Racecourse (based in Berlin) in which winners of its two races are given an invitation to compete in New York Races. The Breeder's Cup is now including 32 races in 11 countries as qualifiers for its 13 championship races. 
Breeder's Cup executives are meeting with racing executives from England, Australia, and Dubai to discuss forming a coalition to sell sponsorships (Mullen, 2017).

In 2017, NBC Sports Network aired three international racing events for the first time: Dubai World Cup, Epsom Derby and Royal Ascot. The horse racing channel TVG has entered into an agreement to air races from Australia. Betting on Australian races increased 40\% within the first three weeks of airing under a new enhanced format that included hosts and commentary (Mullen, 2017).

\section{Top Four U.S. Companies (IBIS World, 2018)}

Churchill Downs Inc., with a 13.5\% market share, owns four horse racing tracks, 22 off-track betting operations, casinos, and a gaming website called TwinSpires.com. Churchill Downs Racetrack has been operating since 1875 and hosts the best-known race - The Kentucky Derby. The company had total revenue of $\$ 910.9$ million in 2017 (IBIS World, 2018).

Stronach Group has a 11.9\% market share and operates six horse racing tracks. It hosts the Preakness Stakes race, one of the three races in the Triple Crown. In addition to horse racing, the company owns businesses related to horse breeding, agriculture, and vehicle and medical technologies. It is expected to have revenue of \$51.2 million in 2018 (IBSI World, 2018).

The New York Racing Association (NYRA), with a 7.6\% market share, was founded in 1955 and owns some of the oldest racing tracks in the U.S. It hosts the Belmont Park, one of the three races of the Triple Crown. The company is expected to have a $\$ 14.6$ million profit in 2018 (IBIS World, 2018).

Penn National Gaming, Inc. (PNG) was established in 1982 and has a 7.4\% market share. It has 26 establishments in 16 states that offer gaming, pari-mutuel horse racing, or off-track wagering. The company has 33,000 gaming machines, 4,500 hotel rooms and 800 table games. Most of its revenue is derived through slot machines. It is forecasting revenue of $\$ 3.1$ billion in 2017 (IBIS World, 2018).

The Tote Company is building a new track in Kentucky because of instant racing machines. These machines present a historical race to a participant where the horses, odds, and other information is provided but nothing that would allow the participant to determine the outcome of the past race. The machine then plays a video of the race showing the results.

\section{A SHORT HISTORY AND CURRENT SITUATION OF HORSE RACING IN ONE STATE}

This state is typical in that it has both dog racing and horse racing, as well as casinos. When dog racing slowly declined in popularity, the children of the founders sold the track to avoid repairs. The land is now occupied by valuable office space. In several instances animal activist groups testified against dog racing. Horse racing, while declining in popularity (see above industry analysis), has survived. Many rural families devote their entire careers to raising, breeding, and training horses. Some families have been in the industry for several generations (Eleven horse racing industry statistics and trends, 2018). Many owners and trainers race in this state and several neighboring states. This state heavily regulates horse racing and is part of the national compact.

While horse racing does not have direct competitors, it has successful indirect competitors. In this region, containing this state and its neighboring states, are professional lacrosse, soccer, baseball, football, basketball and hockey in addition to college sports. Other activities in this region include many outdoor activities, parks, and resorts. While dog and horse racing used to be extremely popular, these indirect competitors have provided other outlets for discretionary time and money thereby eroding the popularity of horse racing (IBIS, 2018).

The state has limited Indian casinos and no racinos so casinos and horse racing are separate legal entities and have separate regulators. However, to the consternation of the casino owners, they have fallen victim to the same indirect competition and are not as profitable as they were previously. There is some interest in adding casinos to Native American lands but the casinos have mounted political opposition.

Unfortunately, neither casinos nor the horse racing track(s) have banded together against a common enemy - indirect competition. 


\section{THE REVENUE STREAM}

The amount of money waged is called the "handle" with approximately $82.0 \%$ going to the winning bettors (IBIS, 2018). Of the remaining $18.0 \%$ which is known as the takeout rate, approximately $3.5 \%$ goes to state taxes, and the remaining $14.5 \%$ is split between the track and the horsemen (IBIS 2018). These percentages are different for off track betting where an intermediary also receives revenue. To add complexity, different states tax at different rates. For a race track their profit is defined by earnings before interest and taxes are generally $6.4 \%$ of industry revenue (IBIS 2018).

\section{REGULATION}

The horse racing industry in the U.S. does not have a national central authority like many other sports and has limited national regulations. However, it should be noted that Congress is being increasingly pressured to draft laws to regulate racing and to ban race-day medication (Alvarez, 2017).

States heavily regulate the industry with each state having its own sets of rules (Rhodes, 2016). Some states belong to a compact or association of regulators which suggests guidelines or model rules for many aspects of the sport (Association of Racing Commissioners International, 2018). These model rules are guidelines only and not required. Consequently, states may follow some but not all the model rules (Association of Racing Commissioners International, 2018).

State regulations address issues such as licensing requirements, the number and location of race tracks, medication, how horses are prepared and trained, the licenses required by jockeys, trainers, owners, pony persons and others at the track. Regulations may limit the purses (amounts paid to owners), and taxes.

In 2000 the Interstate Horse Racing Act was amended to allow online horse race betting (Pandel, 2016). Therefore, some states allow online horse race track betting and others do not (Pandel, 2016). Proponents argue that horse racing is a proper balance between different forces: people who like to gamble by developing their handicapping skills, who enjoy studying the jockeys, trainers and owners, and who like to see races from scenic areas around the world (Pandel, 2016; The Jockey Club, 2017).

However, racing will come under future scrutiny. HorseRacing.com (2019) argues that the states and Federal Administration need to review the laws and regulations over online gambling including horse race betting (Horse Racing.com, 2018). The driving force for future scrutiny is advances in technology because technology makes it more difficult to regulate online gambling.

In addition, there are public concerns that children can access gambling online (Horse Racing.com, 2018). Some critics argue that more laws about children gambling are overdue (Pandel, 2016). The industry counters that it has established systems to prevent this such as parental locks and controls and that these parental devices are sufficient (Horse Racing.com, 2018).

Another area of public concern is horse medication (American Horse Council, 2016). Activists and lawmakers are increasingly concerned. Most states follow the model rules which strictly limit medication and have uniform rules for violations, punishments, fines, suspensions of licenses and other rules. These model rules clearly specify what medications can and cannot be used. They also recommend stiff penalties for trainers who violate the rules from fines up to license suspensions. Many states collaborate with their punishments so that an infraction in one state disallows a trainer to move to another state that participates in the compact.

\section{TRENDS}

American Pharaoh created new excitement in the sport where profits and wagering has declined. The years of 2015 and 2016 were different with $\$ 3.4$ billion wagered on US races a 4 percent increase. (Pandell, 2016).

Racetracks may have digital betting sites and new online sports networks but Pandel (2016) remarks that these are still old fashioned. 
Of special note is that many of the casual gambling sites have new betters. Unfortunately, few new betters frequent the race tracks. For example, none of the Derby Jackpot (the new online gambling site) users bet regularly. About $66 \%$ of these are men with an average age of 40 which is three years younger than the average NFL fan (Pandel, 2016). Pandel (2016) argues that horse racing needs to market to this group because they have disposable income and they do gamble, but they do not have the patience to learn the complexities of the sport and they cannot bet on avatars.

The public is increasingly concerned with abuse from overuse and medication. This includes painkillers, anabolic steroids, muscle relaxers and bronchodilators many of which are common practice but also heavily regulated. Animal activists increasingly push for drug reforms. They are also concerned with what happens to retired racehorses. Many have the misconception that racehorses end up in slaughter houses in Mexico and Canada (IBIS, 2018).

Sports Gambling presents the biggest unknown trend that may impact horse racing. Current federal and state legislation is in great flux with a recent Supreme Court decision that struck down previous federal legislation barring the practice in the U.S. (Alexander, 2008). As the Federal and state governments grabble with the issue, more laws or regulations may be enacted that could spill over and affect horse racing either positively or negatively. If horse tracks provide for sports betting it could bring in the younger generations. However, it could impact horse tracks negatively if other entities do not allow horse tracks to provide it or if new regulations spill over and affect horse racing.

The Supreme Court in Murphy v. Athletic Associations (2018, May 14) declared that the Professional and Amateur Sports Protection Act of 1992 (PASPA) was unconstitutional. PASPA had barred states from allowing betting on sports events. Under PASPA only a few places such as Nevada and casinos allowed sports betting. New Jersey led in overturning the act and is actively pursuing supporting regulation, but still faces significant opposition from athletic associations.

Other federal laws complicate the spread of sports gambling. First the Federal Wire Act prohibits betting or wagering (Federal Wire Act, 18 U.S.C. section 1084 (1961):

Whoever being engaged in the business of betting or wagering knowing uses a wire communication facility for the transmission in interstate or foreign commerce of bets or wagers or information assisting in the placing of bets or wagers on an sporting event or contest, or for the transmission of a wire communication which entitles the recipient to receive money or credit as a result of bets or wagers, of for information assisting int the placing of bets, or wagers, shall be fined under this title or imprisoned not more than two years or both.

A 2011 opinion by the Acting Assistant Attorney General Criminal Division argued that the Wire Act only applied to sports gambling (Vardi, 2011). But a November 1, 2018 opinion reversed the earlier opinion and argues that the Act is not limited to sports gambling and thus hints that internet gambling, or any kind would fall under the Wire Act (Memorandum Opinion for the Acting Assistant Attorney General Criminal Division November 2, 2019). This ruling placed the Wire Act in conflict with the Interstate Horse Racing Act which does allow online gambling on horse races and theoretically would take precedence since it specially mentions horse racing.

States pursing sports betting can argue that their sports betting will occur only within their states. They can vet betters for their age and location. New software technology allows them to disallow attempts by users who are not the right age and the software can locate their physical presence within a few feet. This would not allow users who are not the right age or not inside the exact state lines to gamble with their mobile devices.

If they operate only within their respective states, they would not spill over state lines, not be in interstate commerce, and thus not come under federal jurisdiction because federal laws such as the Wire Act are based on the United States Constitution's Interstate Commerce Clause.

The Unlawful Internet Gambling Enforcement Act of 2006 (2006) act regulates online gambling. It attempts to prohibit gambling businesses from accepting bets or wager payments over the internet. It does 
specifically exclude fantasy sports that meet its criteria and supposedly skill games, legal intrastate games, and intertribal gambling. It does not explain whether or not between wagering between states on horse racing is still legal. Critics of this law claimed that many senators did not see the whole bill before it was put in front of them, that it was added at the last minute to a non-controversial bill (Prohibition Reincarnated, and that it does not deal with the dangers of online gambling (Alexander, 2008).

The unknowns are what do the various federal laws allow or disallow, will other states allow sports gambling, will horse tracks be allowed to participate, and will it pull in younger betters (Horse Racing.com, 2018;Furman, 2015; Leishman, 2016; Lewczak,, 2006: Angwin, 2004; Boudway, 2018; Miller, 2013). The biggest unknown is how the different federal and now state laws will be resolved? Next, several states are already pursuing sports betting in their states (Maese, 2018; Miller, 2013). If they allow horse tacks to provide sports betting, then the tracks may be able to attract younger generations and entice them with sports betting and horse race betting. If these states allow sports betting but exclude horse tracks, then tracks may never reach these younger generations. Other entities such as casinos or the fantasy sports entities such as FanDuel and DraftKing are going to argue that they want the access to sports betting.

\section{REVERSING THE TREND? MARKETING AND BRANDING ISSUES}

The image of betters as older cigar smoking white males is not that inaccurate. The average fan is 51 years old and these fans are literally dying off. Many younger fans find the betting complicated, worry about over medication and overworked horses, and do not enjoy the tracks $(43 \%$ said the race track bathrooms were "icky") (Pandell, 2016). With the aging of horse racing and its target market of older men, can it appeal to the younger generations? Is the industry neglecting the 78.0 million baby boomers born between 1946 and 1964- who are a more receptive audience (IBIS 2018). As this group ages they will increase at a rate of $1.4 \%$ to 117.2 million people by 2022 . They live longer, have accumulated wealth and are a significant portion of the attendees at major sporting events at the National Football League and National Hockey League. They will have more time and money in the future (IBIS 2018).

Some tracks are trying marketing and promotion tactics such as: T shirts, caps and drinks tailored to younger people. Others have restaurants, slot machines, and pony rides for children (Scott, 2019; IBIS 2018). Racing is also being promoted over social media. For example, the website www.racingfuture.com was created to inspire a new generation of fans to enjoy the sport of horse racing. They can also be found on Facebook, Instagram and Twitter (The Best Horse Racing Marketing Ideas, 2018).

Racing the Future website focuses on ideas from around the world to attract younger audiences. In Australia, a television series aimed at racehorse owners was created. In the US (Washington), an "Emerald Racing Club" was created to introduce new people to the fun and excitement of racehorse ownership with a low-cost and low-risk opportunity, games, etc. (IBIS, 2018).

In Canada, a game, EquiLottery - the "Greatest \$2 in Sports", is a new way to integrate horse racing and gaming, while at the same time attracting a new audience of potential fans to horse racing (those who play lottery games) (Horse racing integration, 2014). The President and CEO of Racing Future Inc. stated that EquiLottery is the best idea he has seen in ten years for implementing a commitment of fully integrating horse racing with overall gaming strategy (Horse Racing Integration, 2014). Moving betting online is a potential revenue source, but IBIS (2018) notes that the use of third-party providers leaves financial losses for both bettors and horse owners as they lose their share of gaming profits (IBIS, 2018). Churchill Downs got around this issue by setting up its own gaming site TwinSpires.com. Online betting is banned except for horse racing under a federal exemption. However, if online gambling is allowed for other venues the result would be a decrease in revenue for horse racing (IBIS, 2018).

In England, racing fans were asked to "share your passion" for racing and receive free admission. In Ireland, they held a "Go Racing Kids" Club Day at the race course to promote interest and awareness in horse racing among primary school children. Students from local schools took part in demonstrations, heard talks from jockeys and the racecourse manager, and even played with the racehorse simulator. The kids then received a goodie bag at the end of the day and were invited to enter an essay competition based 
on their experience at the racecourse. The top ten finalists and their parents were invited to a special race day and the winner was awarded a laptop (The Best Horse Racing Marketing Ideas, 2018).

Some tracks are attempting to penetrate the under 35 age group with date night events, drink specials, celebrity appearances and concerts. Some have invested in online gaming and smartphone applications. The result has been a slight increase in this age group for the last five years (IBIS, 2017). In the end, the goal is to remain consistent and persistent (The Best Horse Racing Marketing Ideas, 2018). The marketing strategy needs to be consistent in communicating to customers through all forms of promotion, with the first aim of creating awareness across a wide range of mediums (Mueller, 2017).

\section{COMPETITOR ANALYSIS}

Racing competes against all other forms of entertainment such as professional football, baseball, hockey, soccer, basketball, other gaming, and outdoor activities. For example, in the authors' area horse and dog racing used to be one of the few entertainment venues outside of high school and college sports. Now this area has professional hockey, basketball, baseball, lacrosse, football, and soccer. While there are no direct competitors in the area or the state, these indirect competitors pull much of the available time and money from this sport (IBIS, 2018).

\section{CURRENT RACING}

The Kentucky Derby's ending confused the public about the role of the stewards and the rules against one horse impeding or hindering another (Solomon, 2019). The Santa Ann racetrack had another catastrophic injury (a horse had to be euthanized) (Chairsui, 2019). The 2019 Kentucky Derby ran amid public controversy. A recent article headlined the exact issue- "Horse racing has an image problem" (Chairsui, 2019). Conversely, Horse Racing.com argues that many families raise and train horses which is passed down from generations and many participants enjoy their skill at handicapping (Horse Racing.com, 2019).

\section{CONCLUSION}

As racing enters the next decade, will it find a way to appeal to new markets and demographic groups (Innovative Racing, 2015)? Will this century old tradition survive the forces against it? As this case explains, a lot has been done in the last decade to try to entice younger generations to enjoy horse racing. How will this fair in the future, and what can companies do to capture these younger demographics?

\section{ACKNOWLEDGEMENT}

An abstract of an earlier version of this case was presented at the Western Decision Sciences then modified.

\section{REFERENCES}

Alvarez, A. (2017). Cold to trot: Competition from casinos and lotteries has hurt profitability. IBISWorld Industry Report: Horse Racing Tracks

American Horse Council. (2016). Annual Report. American Horse Council Website. http://www.horsecouncil.org/

Alexander, G. (2008). The U.S. on tilt: Why the unlawful internet gambling enforcement act was a bad bet. Duke Law and Technology Review 5.

American horse racing vs. the world: What's the same, what's different. (2017, December 14). The Sport. Retrieved from https://www.americasbestracing.net/the-sport/2017-american-horse-racing-vs-theworld-whats-the-same-whats-different. 
Angwin, J. (2004, August 2). Could U.S Bid to Curb Gambling on the Web Go Way of Prohibition? The Wall Street Journal.

Association of Racing Commissioners International.com. (2018).

Boudway, I., \& Novy-Williams, E. (2018, April 16). The Big Bet on Sports Betting. Bloomberg Businessweek, (4565), 63-65.

Chairsui, J. (2019, May3). Horse racing has an image problem. Wall Street Journal.

Dess, G. G., McNamara, G., Eisner, A. B., \& Lee, S. (2019). Strategic Management: Creating Competitive Advantages, $9^{\text {th }}$ Ed. New York, N.Y. McGraw Hill.

Eleven horse racing industry statistics and trends. (2018, April 9). Retrieved from https://brandongaille.com/10-horse-racing-industry-statistics-and-trends/

Federal Wire Act. (Also known as the Wire Act or Wire Communication Act). (1961). 18 U.S. C. Section 1084.

Furman, T. (2015, October 1). Going all in: New Jersey and the sports betting landscape. DePaul Business and Commerce Law Journal, 14(1), 111-131.

History of horse racing. (2009, April 7). Retrieved from http://www.winningponies.com/horseracinghistory.html

Horse racing facing in revenue, popularity. (2016, May 8). Newsweek. Retrieved from http://www.newsweek.com/horse-racing-fading-revenue-populariyt-457123.

Horse racing industry trends. (2018, May 9). Horse Racing.com website. Retrieved from www.horseracing.com/trends/

Horse Racing Integration: EquiLottery Is Critical to Horse Racing. (2014). Retrieved from http://www.racingfuture.com/content/horse-racing-integretation-equilottery-critical-horse-

Horse Racing.com website. (2019).

IBIS World industry report OD4372 Horse racing tracks. (2017, April). IBIS World.

IBIS World industry report OD 4372. Horse racing tracks. (2018). IBIS World.

Innovative Racing. (2015). A closer look at why the horse racing industry needs innovation and a brief history of the sport. Retrieved from www.innovtativeracing.com.

Interstate Horse Racing Act 15 U.S.C. section 3001 et seq Pub L. 95-215.

Leishman, N. C. (2016, December). Daily Fantasy Sports as Game of Chance: Distinction Without a Meaningful Difference? BYU Law Review, 9(3) 1042-1080.

Lewczak, J. (2006, January). Safe Bet? Risks outweigh rewards in trying with online gambling sites. Legal Briefs Promo, (2), 19-20.

Maese, R. (2018, May 14). What the Supreme Court's sports gambling decision means. The Washington Post.

Memorandum Opinion for the Acting Assistant Attorney General Criminal Division. (2018, November 2).

Miller, C. K. (2013, July). The Internet Gambling Genie and The Challenges States Face. Journal of Internet Law, 17(1), 19-35.

Milbert, N. (2008, January). ADWs - Advanced Deposit Wagering. Tribune. Retrieved from https: www.usracing.com/advance-deposit-wagering.

Mueller, L. (2017, May1). U.S. racing industry learning from global success. The Sports Business Journal. Retrieved from https://www.sportsbusinessdaily.com/Journal/Issues/2017/05/01/InDepth/Horse-racing-global.aspx

Mullen, L. (2017, May 1). U.S. racing industry learning from global success. Sports Business Journal. Accessed at www.sprotsbusinessdaily.com/Journal

Murphy v. National Collegiate Athletic Association. 584 U.S. (2018, May 14). No. 10-476;138 S. Ct. $1461 ; 200$ L. Ed. $2^{\text {nd }} 854$.

Pandell, L. (2016, May 21). The quest to make horse racing cool again. Wired. Retrieved from www.wired.com

Professional and Amateur Sports Protection Act (Known as PASPA). (2015). 28 U.S.C. section 3702. 
Rhodes, J. (2016, May 8). Horse racing fading in revenue, popularity. Newsweek. Retrieved from www.newsweek.com

Scott, J. (2019, February). Track changes. Central Penn Business Journal, 35(6), 52.

Solomon, M. (2019). Preakness 2019: Latest Saturday odds, best bets and how to play the field. Retrieved from Forbes.com.

The Best Horse Racing Marketing Ideas. (2018). Retrieved from http://www.racingfuture.com/content/best-horse-racing-marketing-ideas

The Jockey Club. (2017, December 14). American horse racing vs. the world: What's the same, what's different. Retrieved from www.americasbestracing.net/the-sport

The U.S. on Tilt Why the Unlawful Internet Gambling Enforcement Act is a Bad Idea. (n.d.). Law Duke University.

Unlawful Internet Gambling Enforcement Act (Known as UIGEA). (n.d.). 31 U.S.C. sections 5361-5367.

Vardi, N. (2011, December 23). Department of Justice Flip-Flops on Internet Gambling. Fobes.com. 


\section{APPENDIX 1}

\section{A short primer on wagering \\ (From Pandel, 2016)}

\section{Single horse single race}

Win- the horse must finish first.

Place - the horse must finish first or second

Show- the horse has to finish first, second or third.

Multiple horse in the same race types of bets

Exacta- picking the first two finishers in order

Quinella- picking the first two finishers in either order

Trifecta-picking first three finishers in order

Superfecta- picking the first four horses in order

Pentafecta (Super High Five) picking the first five finishers in order

Multiple race wagers

Daily double- pick winners of two races in a row

Pick 3 - pick winners of three races in a row

Pick 4 - pick winners of four races in a row.

Pick 5- pick winners of five races in a row.

Pick 6- pick winners of six races in a row.

\section{Advance Deposit Wagering}

A new trend is advance deposit wagering where a participant can go to a provider, set up an advance deposit account, and use the account to make wagers on horse and dog races. Participants can use online or phones. In some cases, credit card companies allow wagers which are settled at the month's end. The tracks, trainers, and state governments sometimes receive portions of the ADW revenues (Milbert, 2008). Companies include AmWager.com, GreyhoundChannel.com, Offtrackbetting.com, BetAmerica.com, Trackinfo.com, NYRABets.com, TwinSpires.com, Xpressbet.com and possible others in the future. 


\section{APPENDIX 2}

\section{Organizations Involved in Horse Racing}

American Horse Council

"Its goals are: promoting and protecting the equine industry, unifying the industry, and advocating for the social and economic significance of the industry to members of Congress, the media, and the general public" (American Horse Council 2016 Annual Report).

Others from (American Horse Council 2016 Annual Report)

American Association of Equine Practitioners

The Jockey Club

American Quarter Horse Association

United States Trotting Association

US Equestrian Federation

Keeneland Association

National Thoroughbred Racing Association

Thoroughbred Racing Associations of North America

\section{AN INDUSTRY IN DECLINE: CAN U.S. HORSE RACING TURN THE CORNER? THE TEACHING NOTE}

\section{OVERVIEW OF THE CASE}

The case provides the history, current environmental analysis, and issues facing horse racing in the US. While declining in the US, the sport is very popular in other countries such as the UK and the middle east.

\section{SUGGESTIONS FOR USING THE CASE}

Several classes could use the question of how to turnaround a declining industry. These include beginning management, strategic planning, brand marketing, or marketing strategy classes.

\section{LEARNING OBJECTIVES}

1. Analyze company actions by applying brand management principles.

2. Analyze the macro-environmental forces.

3. Analyze the competitive environment using Porter's Five Forces Analysis.

4. Evaluate the leadership and actions taken.

5. Make recommendations for future courses of action.

\section{SUGGESTED ASSIGNMENT QUESTIONS}

1. How might companies in this industry segment, target, and position (STP) in order to appeal to older and younger generations?

2. What strategic actions should the racing industry take to reverse the decline?

3. Prepare an analysis of macro-environmental factors and discuss how they impact the industry using a SWOT analysis

4. Prepare a Porter's Five Forces analysis of the industry. 
5. What are appropriate actions a company might take in a slow declining market? Are turnaround strategies workable in this industry?

6. What recommendations would you make to leaders in this industry?

\section{ANSWERS TO QUESTION 1: HOW MIGHT COMPANIES IN THIS INDUSTRY SEGMENT, TARGET, AND POSITION (STP) IN ORDER TO APPEAL TO OLDER AND YOUNGER GENERATIONS?}

STP, or segmentation, targeting and positioning, is a marketing tool used to differentiate, attract, retain and grow customer bases for products. Segmentation is taking a whole market and identifying meaningful groups of different customers. Targeting is then selecting which segment(s) of these customers to serve. Finally, positioning is implementing the chosen image and appealing to the chosen segment(s). This usually includes a positioning proposal.

Companies in this industry should reposition themselves by segmenting the market for horse racing, and targeting older consumers, younger consumers (millennials), females, and families. The older generation, the baby boomers, have income and leisure time, so they are a great market to position to in terms of being a fun leisure activity. The younger generation is interested in doing more than just watching horse racing, so using digital betting apps while watching, playing games to earn free horse racing gear, playing drinking games while watching, hosting date night events, drink specials, celebrity appearances, concerts, etc.

Companies can host family events that will get the millennial generation to attend and bring their kids with them (kids horse racing on stick horses, pony rides, etc.)

\section{ANSWERS TO QUESTION 2: WHAT ACTIONS SHOULD THE RACING INDUSTRY TAKE TO REVERSE THE DECLINE?}

\section{First}

The industry needs new directions on several strategic fronts. First, they need to continue to monitor Congress, and state legislatures to ensure that adverse legislation is not passed. Any legislation promoted by an animal rights group would destroy the industry.

\section{Second}

The industry could use national and local advertising promoting the virtues of the industry including the beauty of watching high performance equine athletes run. Other possibilities are promoting the history of racing and the often family-oriented horse farms. They could advertise responsible gambling similar to alcohol manufacturers.

\section{Third}

They need to work collaboratively with the gambling industry. Historically, both sides see the other as competitors. This will take a refocus of both sides' perception- the main competitive threat is from indirect competitors- other sources of leisure and use of discretionary income such as professional sports etc.

\section{Fourth}

They need aggressive marketing aimed at the millennials and Generation $\mathrm{Z}$ as discussed below. 


\section{ANSWERS TO QUESTION 3: PREPARE AN ANALYSIS OF MACRO-ENVIRONMENTAL FACTORS AND DISCUSS HOW THEY IMPACT THE INDUSTRY USING A SWOT ANALYSIS.}

\section{Strengths}

The industry has a long and rich history and a faithful, although decreasing customer base. This base is knowledgeable, follows the industry, and has disposable income for their leisure activity. The industry publishes racing programs that provide complete information on racing. Many tracks have off site betting in other venues. The industry is well developed with relationships across the US. The latest change to the federal law allows Internet gambling.

\section{Weaknesses}

The industry has several negative forces acting on it. First is the declining customer base as this group ages. Second is the lack of appeal to younger generations. Animal rights groups apply considerable negative pressure and are increasingly vocal and powerful. These groups have succeeded in closing many dog racing tracks in the US.

\section{Threats}

The biggest threat comes from the decreasing customer base. Current generations such as the millennials and generation $\mathrm{Z}$ are addicted to their personal devices to receive their entertainment and news. They do not understand the racing programs and may not have the patience to understand it. The activities of the animal rights groups present an ongoing threat. Publicity of horses racing injuries which would provide fuel for these animal rights groups. A possible threat is additional governmental regulation at either the state or federal levels.

\section{Opportunities}

These include current generations and internet gambling. Millennials and generation $\mathrm{Z}$ present a large customer base if the industry can spark their interest. If the industry can figure out how to put racing on their mobile devices, make it more understandable, engage them interactively, and allow interactive competition with their internet colleagues, than this would open new markets.

\section{ANSWER TO QUESTION 4: PREPARE A PORTER'S FIVE FORCES FOR THE INDUSTRY.}

\section{Rivalry between competitors}

This rivalry is limited because most horse tracks are not in the same geographical location so do not directly compete for local customers. However, many tracks have off site betting facilities that receive signals from several tracks allowing geographically separated tracks to compete for the gambler's attention. Some completion comes from casinos who compete for gamblers' dollars. However, some tracks and casinos have combined to create racinos with both types of gambling.

\section{Competition from substitutes}

There are numerous indirect competitors for their customers' leisure time and discretionary spending. These include professional sports, college sports, local school sports, gaming, video, indoor and outdoor activities, games, and internet gambling.

\section{Power of Suppliers}

Most suppliers of materials like electricity, water, or supplies have no power over companies in this industry. However, trainer, owners, jockeys and their associations do have power. Tracks must negotiate, collaborate, contract, and work together on numerous issues. 


\section{Power of Customers}

Customers have a lot of power given the indirect competition for their leisure time dollars.

\section{Barriers to Entry}

The barriers are very substantial from the fixed capital costs of building tracks, barns, video equipment, and computers to capture the bets, coordinate the bets from all over the US, and determine the winners. In addition to these huge capital costs, entrants must receive licenses and approval from their state regulators.

\section{ANSWERS TO QUESTION 5: ARE TURNAROUND STRATEGIES WORKABLE IN THIS INDUSTRY?}

Des, McNamara, Eisner, and Lee's (2019) first turnaround strategy is to perform a careful analysis of an organization's internal and external analysis. They suggest selling unused assets, cutting costs, reducing unprofitable product lines, and improve productivity (Dess et al, 2019). Some tracks have unused assets but most use all their assets just to provide racing. Some could cut costs by judiciously reducing unprofitable races or unprofitable times, but this limits their ability to send their race signals to off-site venues.

If online gambling becomes more accepted, the ability to send races to the younger generations mobile devices could be an untapped market. Another untapped market is to follow the lead of many ski resorts which have built up complete and profitable summer activities that use their facilities in the off seasons. This unexplored market would use their fixed property assets for events tailored to the younger generations such as concerts, shows, or events featuring the positive aspects of racing.

\section{ANSWERS TO QUESTION 6: WHAT RECOMMENDATIONS WOULD YOU MAKE TO LEADERS IN THIS INDUSTRY?}

This industry needs to do all the above recommendations including monitoring legislatures, marketing to millennials, working with casinos, and repositioning and rebranding their products. They must determine ways to interact with younger generations. The best strategy would be to determine how to get their races on the younger generations' mobile devices. 